\title{
6 \\ The German Land parliaments (Landtage)
}

\section{Historical development}

In the Kaiserreich of 1871-1918, the Constitution gave the central government only a brief catalogue of powers, with all other powers reserved for the states; however, the central state also had concurrent powers and implied powers. Over time the national government assumed more powers through constitutional changes and legislation which also had to be passed by a second chamber, the Bundesrat, that represented the mostly monarchical governments in the states. The state parliaments had no voice in these developments or in the many cooperative agreements signed by the state governments to bring about more uniformity in the country. ${ }^{1}$

In the Weimar Republic of 1919-33, the monarchical governments in the states (now called Land (singular) and Länder (plural)) were replaced by governments dependent on majorities in the Land parliaments (Landtage). But these democratically legitimated governments now faced a central government with more domestic powers than its predecessor had enjoyed. In contrast to 1867 and 1871, the state parliaments had no role in approving the Constitution in 1919. Rather, a nationally elected National Assembly ratified the Constitution after having given the central government a much longer list of powers, including concurrent powers, than under the Reich Constitution of 1871. The reordering of public finances also had a unitary effect, made necessary in part because of the heavy burdens of the First World War. As a result, the budgetary powers of the Länder were almost completely undermined. In the Reichsrat, which replaced the Bundesrat of the Kaiserreich, the Land governments acted on the basis of political party policy, not on views expressed by the Land parliaments (although, of course, the governments had to have majorities in the parliaments). Conferences of various Land officials with 
the goal of providing for more uniform Land legislation also helped undermine the Land parliaments. ${ }^{2}$

With the accession of Adolf Hitler to power in January 1933, the Land governments were soon authorized to bypass the Land parliaments by passing laws through "simplified legislative procedures." Following the national elections of 31 March 1933, first Communist, then Socialist, seats were denied in all parliamentary bodies. In April the Land parliaments lost the right to pass votes of no-confidence, and in October 1933 the state parliaments were dissolved along with the national parliament, the Reichstag. Exactly one year after Hitler came to power, 31 January 1934, the Land parliaments were officially disbanded. ${ }^{3}$

\section{The Land parliaments as legislatures today}

\section{Land parliaments and the Basic Law}

Local and Land governments were the first to be established after the Second World War. The first elections were held in 1946 and 1947, depending on the occupying power. The governments and legislatures formed then became the building blocks for the establishment of the Federal Republic in 1949, and then as now they were important training and recruiting grounds for national office. From the beginning, all of the Länder have had only one chamber, called the Landtag in the thirteen territorial Länder, Bürgerschaft in Bremen and Hamburg, and Abgeordnetenhaus in Berlin. The one exception was Bavaria, which had a corporatist Senat as a second chamber with limited powers until it was eliminated by a popular referendum in 1998.

We have seen in previous chapters that according to Article 30 of the Basic Law, the Länder are responsible for "governmental powers" unless the Basic Law provides otherwise. Article 70 then states that "the Länder have the right of passing legislation insofar as this Basic Law does not grant legislative authority to the federation." The Basic Law provides for three kinds of national legislation: exclusive, concurrent, and framework. Article 73 enumerates exclusive legislation, including defense and foreign affairs, currency, customs, citizenship, immigration, postal services, etc. Areas of concurrent legislation are found in Article 74 and include civil and criminal law, public welfare, economic affairs, nuclear energy, labor relations, transportation, etc. An especially controversial provision is found in Article 72, which gives the federal government the right to pass 
concurrent legislation in favor of promoting equivalent living conditions throughout the country "if required." This very general provision, which covered a wide range of activities, ${ }^{4}$ was tightened somewhat in the constitutional amendments of 1994 by substituting "if required" for "if needed." Unlike concurrent legislation in the United States, where the national government prevails only in cases where specific national and state provisions are in conflict, federal concurrent legislation in Germany preempts all Land legislation in the area of regulation.

Framework legislation is the third area, and it concerns regulation of all public employees, general principles of higher education, regional planning, registration of residence, etc. Federal laws in this category are supposed to leave details to the Land parliaments, which are obliged to act within a reasonable period of time. In general, however, the provisions of the framework laws do not leave the Land parliaments much leeway. ${ }^{5}$

As a result of these many exceptions to Article 30 and Article 70, the national organs, i.e., government, Bundestag, and Bundesrat, are responsible for most legislation, while the Länder are generally responsible for administration under Article 83. This is "the essential characteristic of German federalism" 6 and is generally what is meant when references are made to "dual federalism" in Germany.

This does not mean that the Länder have no influence on federal legislation. We have seen that the Bundesrat, the chamber of the Länder, has an absolute veto over more than half of the legislation passed by the Bundestag and a suspensive veto over the rest. The influence exerted by the Länder in the Bundesrat is, however, exercised by the Land governments, not the Land parliaments.

\section{The party group}

The party group (Fraktion) or parliamentary party (in the United States, "caucus"), is legally a parliamentary organ and is publicly financed. ${ }^{7}$ It the key institution for the German office holder at all levels of government. It is his or her "home" in parliament, and little can be accomplished unless one is a member of a party group. The introduction of bills requires the support of a certain number of deputies, which is the same as the minimum number of deputies required to form a party group. Thus bills are introduced through the party group, which also determines the speakers in debates. The party groups decide among their own members who will serve on the various committees, including investigative committees. The leaders of the party groups form an executive committee to determine the 
agenda of the parliamentary meetings and the time for debate. ${ }^{8}$ Party groups form working groups based on committee assignments, and most of the parliamentary work done by the deputies is done in or for these groups. Thus parliamentary activity is primarily party group activity. ${ }^{9}$

A minimum number of deputies, usually 5 percent of the total membership, is required in order to form a party group. This is generally not a problem, because in the German proportional representation system a party normally needs 5 percent of the total vote in order to enter parliament. The exception is for candidates who win a direct seat in a single-member district. In this case the candidate would enter parliament, but unless he or she joined a party group, the deputy would be a lone figure unable to participate effectively in the affairs of parliament. Since Germany is a "party state," independent candidates are rare, and they have no chance of winning a direct seat. At the federal level a party may secure representation in the Bundestag and even benefit from the features of proportional representation in spite of failing to meet the 5 percent vote requirement by winning three or more direct seats. Not until the Party of Democratic Socialism (PDS), the successor to the East German Communist Party (SED), won four direct seats in East Germany in the federal elections of 1990 and 1994, did any party enter the federal parliament under this rule.

German party groups, like their counterparts in most other European parliamentary systems, demonstrate a high degree of unity in both committees and in the plenary meetings. Normally the party group takes a position in support of the recommendations of its working groups. Fraktionszwang, or coercion, is not allowed under Article 38 of the Basic Law for the federal level or under similar provisions in the Land constitutions for the Land parliaments and local councils. But Fraktionsdisziplin, or discipline, is assumed, and members of the party group rarely deviate from the "party line," which is really the party group position based on deliberations among the members of the party group. ${ }^{10}$ On important issues the leadership, of course, exercises a good deal of influence. This is especially the case if the party is supporting the government and feels obligated to back its own ministers in their actions and policies. Sometimes a deputy may find it difficult to maintain unity, as in the case of territorial reforms of local government boundaries that were introduced in the late 1960s and 1970s throughout the West German Länder. ${ }^{11}$ In such cases, which are rare, the deputies may be allowed to abstain. ${ }^{12}$

The party groups are, of course, closely related to the extra-parliamentary political party, but they are part of the parliament, that is, they are "state" institutions that receive generous funding from the Land budget. 
They are not allowed to use these funds for campaigns or other strictly party purposes, but the line may be difficult to draw on occasion. They are supported by the parliamentary advisory service staff, and they may hire additional staff at their own expense. As is the case with committee staff members in the United States, the parliamentary advisory staff assist party group members in many ways and are an important part of the working groups, committees, and the legislative process in general. ${ }^{13}$

The party group leader is usually the most prominent member and the spokesperson for the party in parliament. He or she may be overshadowed by the prime minister or some ministers if the party is supporting the government, but if the party is in opposition the party group leader is in effect the Leader of the Opposition and a probable candidate for prime minister in the next election. The party group leader is also responsible for maintaining unity in the group, since any evidence of disunity is seen by opposing groups as a sign of weakness and disarray. Everyone in the party group knows that the group's effectiveness depends in part on unity, which encourages discipline all the more. ${ }^{14}$ The party group leader is assisted by a general manager, who may or may not be a member of the parliament. As a kind of chief of staff, this person may gain considerable influence and use the position as a springboard for high positions in the future. ${ }^{15}$

\section{The decline of Land legislative powers}

Before one begins any discussion of a decline of Land legislative powers, it should be noted that complaints about loss of powers have existed since the Basic Law was promulgated; however, it would not be correct to conclude that the Land parliaments were not given or have not retained some important legislative powers of their own. These include responsibility for their own organization, including such areas as electoral law and budgets; cultural areas, including not only the arts but also universities, schools and training facilities; church law; much of police law, including construction and water rights; planning and nature conservation; local government law (but within limits of the guarantee of local self-government); radio and television (excluding technical aspects); and a few concurrent powers not assumed by the federal government. ${ }^{16}$ It can certainly be argued, though, that the Land parliaments had their days of glory in the period between 1946 and early $1950 s,{ }^{17}$ before the national government existed ${ }^{18}$ or had begun to act in areas of concurrent legislation that the Länder had already dealt with. The last great hurrahs of the western Land parliaments may have been the educational reforms and 
territorial reorganizations ${ }^{19}$ of the late 1960s and early-to-mid-1970s, while for the new Länder in the East important legislation was passed after unification in the mid-1990s. One can also point today to various administrative reorganization schemes and reforms being discussed or carried out that are designed to increase efficiency and reduce personnel (Schlanker Staat). Attention is also being given to changes in the budget process and control instruments.

But for several decades it has been a kind of conventional wisdom that there has been a decline of Land legislative powers, and those making this case are informed and knowledgable observers. ${ }^{20}$ On the other hand, there have been some dissenters and others who suggest that the standard complaint begs the question. Thus a few voices have suggested that based on statistics on Land legislation, there has been no loss of legislative functions - either in number or in importance. ${ }^{21}$ Others have suggested that the quantity of Land legislation has not really declined so much as its quality. ${ }^{22}$ In another line of argument, Alois Glück, the party group leader of the CSU in the Bavarian Land parliament, has rejected in parliament and elsewhere the thesis that the Land parliaments are less important today due to a loss of legislative powers, because new tasks have been added..$^{23}$ The assertion that they have been reduced to the level of local governments is "absurd." ${ }^{4}$ Indeed, one recent study suggests that the conclusion that there has been a loss of legislative powers depends on the issue area and/or on particular legislative functions (legislative, articulation, control, and public information) as performed separately by the government parties and Opposition. For example, if one does a careful empirical examination of Land legislation concerning illegal drug policies, one finds that over the years since 1968 the Land legislatures were active in varying degrees in performing articulation, control, public information, and innovation functions but were barely active in the lawmaking arena. Thus government parties were more engaged in information functions and the Opposition in control, and, to a lesser extent, innovation functions. ${ }^{25}$ Still another view is that the focus on Land legislative powers seems to confuse the greater legislative functions of a legislature in a presidential-type system and the different functioning of a parliament in a parliamentary system which is based more on the relationship between the government and its supporting majority in parliament versus the Opposition. The government majority carries the responsibility for the exercise of power, including legislative initiatives of the cabinet, and the Opposition has the role of controlling that power in public. ${ }^{26}$ 
Nevertheless, most observers continue to argue that the legislative powers of the Land parliaments have been weakened dramatically over the years for a variety of reasons. One simple explanation is that the most important laws have been passed, and today the Länder are concerned above all with modifying and amending their earlier legislation, filling in the details of federal framework legislation, and providing for the implementation of federal laws that the Länder administer. ${ }^{27}$

It is frequently noted that the constitutional amendments passed since 1949 which enhanced federal powers were approved by the Länder in the Bundesrat, and that they did so voluntarily. ${ }^{28} \mathrm{~A}$ common reason given for the willingness of the Länder to approve such changes from the early 1950s to the mid-1970s, including the preemption of Land legislative powers through federal concurrent legislation, the joint tasks under Article 91a and $91 \mathrm{~b}$, and the financing arrangements under Article 104a, has been the pressure by the media, the political parties, and various interest groups for more uniform living conditions throughout the country. ${ }^{29}$ In the meantime there has been much criticism of this justification, not only because of the growing difficulty of financing measures deemed appropriate to promote more uniformity but also because of the undermining of federalism that it implies. As noted in Chapter 2, Article 72 was amended in 1994 in order to make its provisions less sweeping. Thus the "need" to pass concurrent legislation was changed to "essential" or "required" in order to promote "equivalent" rather than "uniform" living conditions. But the tradition and generally strong popular acceptance of the welfare state, and the public expectations related to a wide variety of public services, make it difficult to maintain differences in these policy areas. ${ }^{30}$ While this has always been a challenge since the Second World War in the West, unification in 1990 with the former and much poorer Eastern territories has helped create severe strains in the welfare state. This has implications for federalism, because there is little support in the East for differences in service levels in the name of Land autonomy.

Not only have the Land parliaments lost powers to the federation. The focus of attention is on the prime minister and his government, ${ }^{31}$ and in virtually all legislative bodies, especially in parliamentary systems, complaints have long been heard about the dominance of governments over the legislatures in the legislative process. ${ }^{32}$ Executive dominance over the parliament is a common theme in almost every textbook on French and British government, and even in the United States, where the national and state legislative bodies are comparatively powerful, it is frequently observed that "the Administration proposes and the legislature disposes." 
In a parliamentary system, the governments usually control the agenda, even if - as in the United States - they cannot always control the results. But in a parliamentary system with strong party discipline, which is typical of Germany, the parliamentary majority is generally bound to follow the proposals of the government. Internal disagreements within the majority party or coalition may lead to compromises or changes of various kinds, but the government usually prevails in a parliamentary vote. The result, of course, is a weakening of the parliament vis-à-vis the government and an undermining of separation of powers; in effect, separation of powers exists in the relationship between the government and its majority in parliament on the one hand and the Opposition on the other. It is the role of the parliamentary Opposition or sometimes of groups outside of parliament, such as the student protest movements and the citizens' initiatives in Germany in the 1970s, to criticize the government openly and offer alternatives. Some German Land deputies may complain about the restrictions imposed by party discipline when they are in the majority and about the general futility of their criticisms when they are in the Opposition, but these conditions seem inherent in a functioning parliamentary system.

A more complicated explanation for the weakening of Land parliaments is the development of cooperative federalism. Though Konrad Hesse pointed to the emergence of a "unitary federal state" in Germany at the beginning of the $1960 \mathrm{~s},{ }^{33}$ cooperative federalism did not begin "officially" until after the Finance Reform of 1969, which provided for joint taxes as the most important sources of revenue; for joint planning and financing of a variety of activities that were formerly the sole responsibility of the Län$\operatorname{der}$ (Article 91a and 91b); and for federal grants under Article 104a, paragraph 4, that required Land financial participation. Especially from the 1950 s to the 1970s, the federal government assumed increasing legislative powers through constitutional change and preemption of Land powers through concurrent legislation. The Länder were compensated to the extent that the Land governments had the right to joint decision making in these legislative arenas in the Bundesrat (at least if they were in the majority) and in their authority in many cases to issue regulations that bypassed the Land parliaments. The Land governments also engaged increasingly in numerous cooperative arrangements with other Länder through a wide variety of conferences and committees ranging from the conferences of Land prime ministers, Land ministers - e.g., the Conference of Education and Culture Ministers (KMK) - and numerous conferences and meetings of bureaucrats that produced much pressure for uniformity throughout the country, in large part through model legislation. ${ }^{34}$ The 
governments' majorities in the Land parliaments are reluctant to reject decisions made in these conferences, ${ }^{35}$ so the governments generally have a free hand unless there are disagreements within the majority party or coalition. (Though rare, there have been instances when a majority party did reject a government's decision made at a conference with officials of other Länder, thereby forcing changes to be made. ${ }^{36}$ ) The concept of Politikverflechtung - roughly equivalent to the American concept of intergovernmental relations - reflects this web of joint planning, joint decision making, and shared financing between the federal and Land governments and the wide-ranging voluntary cooperation and coordination among the Länder themselves that have been characteristic of German federalism since at least the late $1960 \mathrm{~s}^{37}$ Indeed, some observers believe that cooperation and coordination between the federation and the Länder and among the latter via the numerous conferences and meetings raise a question of whether the practical effect is not an unconstitutional undermining of Land parliament powers. ${ }^{38}$ In any case the political weight of the Länder is based more on the Land governments than on the parliament, which is one reason why some observers speak of "executive federalism" in Germany. ${ }^{39}$

Another important reason for the loss of legislative powers by Land parliaments that is rarely mentioned in the literature is the accumulation of large debts by the Länder. The high interest payments, not to mention the principal, have lessened considerably the parliamentary room to maneuver in various policy arenas. In some Länder, such as the Saarland and Bremen, the parliaments can hardly think responsibly of new policy initiatives. ${ }^{40}$

In addition to the various domestic pressures that have served to weaken the Land parliaments, the EC/EU has enacted numerous regulations affecting Land powers. Indeed, the federal government was able in the past under the old Article 24 of the Basic Law to transfer sovereign powers, including Land powers, to international organizations. This meant that the federal government could vote on measures in the EC Council of Ministers in Brussels affecting exclusive Land powers, such as education, training, and culture, over which it had no authority in Germany. ${ }^{41}$ For this and other reasons, the Länder insisted on and finally, in the late 1980s and early 1990s, succeeded in gaining rights of consultation and participation via the Bundesrat in decisions affecting their powers (see Chapter 7).

In constitutional terms, the weakening of the Land parliaments can only go so far, even though some observers would argue that the limits have been reached. Article 20, para. 1, of the Basic Law says that Germany is a "democratic and socially conscious federal state," and Article 79, para. 
3, prohibits amendments "affecting the division of the Federation into Länder." The Länder are considered to be "states" - though not in the sense of international law - which means they must retain an essential core of responsibilities. These include Land parliaments with a minimum of exclusive legislative powers. ${ }^{42}$ It is sometimes argued that the Länder have been compensated for losses of parliamentary powers by increased participation of the Land governments in the Bundesrat and various forms of cooperation with the federal government and other Land governments. Most constitutional scholars reject this view, pointing out that the Land parliaments have no right to direct the governments in their decisions in the Bundesrat, which is a federal organ, and they note that the parliaments are generally ignored in decisions made in the wide variety of conferences between their governments and the federal and other Land governments. ${ }^{43}$ On the other hand, modest changes were made in the Basic Law in 1994 which should help to protect the Land parliaments from further erosions of their powers, and the consultation and participation rights gained by the Länder via the Bundesrat with respect to the EU might even serve to strengthen the Länder in the process of European integration. But any further loss of Land legislative powers, which has been an issue since the early years of the Federal Republic, ${ }^{44}$ could affect the legitimacy of the German federal system..$^{45}$

\section{Functions of the Land parliaments today}

Walter Bagehot and Max Weber suggested long ago that parliaments have multiple functions besides legislation, and it is no surprise that close observers of the Land parliaments also see them as performing several functions. ${ }^{46}$ In addition to the legislative function, one can distinguish among an electoral and recruitment function, that is, the election of the prime minister and his or her cabinet (only in seven Länder can the prime minister select his or her cabinet without parliamentary approval); a political control function, which serves as a check on the executive branch and overlaps with a public information function; a debating function, which has to do with educating the public as well as with information and communication; and a representation and articulation function, which serves as a means of expressing a plurality of public wishes, expectations and concerns in the policy making process. Finally, perhaps as a part of the previously named function, one can point to a service function, which is so important in the United States but sometimes ignored in the German literature on Land parliaments. 


\section{Legislative functions}

Given the strong role of legislative bodies in the United States, most Americans naturally think of these as having legislation as their main function. But even in the United States legislatures have other functions, such as controlling the executive through legislative oversight, confirming the appointments of various officials, and performing numerous representation and service functions. In parliamentary systems governments depend on majority support in parliament in order to remain in office, but there is also a strong tendency, especially in disciplined political party systems such as the German and British, for the majority party or coalition to support government policies with relatively little open criticism. Legislative initiatives come largely from the government, and though some changes in government bills may be made in committee or behind the scenes, the parliamentary majority is expected to support the government's agenda. Nevertheless, laws cannot be passed without the parliaments, so that at least formally they retain ultimate power in the legislative process. ${ }^{47}$

According to one close observer of Land parliaments, legislation today takes up little time in the Landtage - about one-sixth of the plenary sessions. ${ }^{48}$ As noted above, their legislative powers have been weakened during the past decades by constitutional changes, cooperative administrative arrangements with the federal government and other Länder, and encroachments by the EU. As a result, many critics have suggested that the Land parliaments are largely superfluous bodies with only limited powers of any significance. Even in those areas over which they have retained some powers, the majorities are constrained by the need to support the government, and the Opposition forces have little or no chance to prevail. At best they may exercise some influence in committee deliberations hardly noticed by the general public. ${ }^{49}$ As noted above, this view is not accepted by all observers.

\section{Electoral and recruitment functions}

In a parliamentary system the electoral and recruitment functions are often more important than the legislative function. The prime minister as well as the Opposition candidate for chief executive in the previous election usually emerge from the Land parliament ${ }^{50}$ or a previous Land cabinet (or, sometimes, from a federal cabinet post), and he or she generally has the strongest role in selecting the cabinet ministers. This is especially the case in the seven Länder where the prime minister appoints individual cabinet members without parliamentary interference, but even then the wishes of and pressures from the parliamentary party and/or coalition 
partner must be taken into consideration. Pre-election agreements can also limit the prime minister's influence. ${ }^{51}$

There are some differences among the Länder in the role of the parliament in selecting cabinet ministers. For example, in the city-states the parliament elects the entire cabinet: in Berlin, first the lord mayor, then the cabinet; in Bremen and Hamburg, first the Senat (cabinet), which then elects the lord mayor. In six of the territorial states, the parliament elects only the minister-president (prime minister), whose cabinet appointees then require parliamentary approval. In seven Länder the parliaments do not control the prime minister's formation of the cabinet, which is also the case at the federal level. But in almost all cases ministers are recruited from the parliaments. "Outsiders" do become ministers on occasion, but they usually have some political experience elsewhere if not in the parliament. ${ }^{52}$ Only in Bremen and Hamburg is there a rule of incompatibility between executive and legislative office. ${ }^{53}$ The parliamentary majorities are also involved in the appointment of key civil service positions, such as state secretaries, possibly some department section chiefs (who, however, are usually career civil servants), and directors of government districts (Regierungsbezirke) who are considered to be "political bureaucrats." Parliamentary deputies sometimes seek these positions themselves. In the city- states leadership positions in public enterprises are also important patronage posts, and there are frequent complaints about the party patronage (Filzokratie) that is often associated with them..$^{54}$ Finally, Land deputies elect judges to their state constitutional courts, and every five years they select - mostly from among their own members - half of the electors of the Federal Assembly which elects the Federal President as ceremonial head of state.

\section{Political control functions}

A third major function of the Land parliaments is control of the government and bureaucracy. Indeed, given the importance of the Länder in administering most laws, ${ }^{55}$ this is seen in much of the literature as their most important function. ${ }^{56}$

The instruments of control include parliamentary questions, both oral and written; the right to demand that responsible ministers respond to questions personally and that ministers submit reports to the parliament (Zitierrecht and Berichtsersuchen), which may be taken up either in the plenary meeting or by committees; the current-issues question time (Aktuelle Stunde) for short questions and answers; resolutions, which can deal with a general question without specifying a particular address, for 
example, the Land parliament condemns the actions of skinheads against asylum seekers, or demands that are legally nonbinding calling on the Land government take certain actions; a vote of no-confidence, which, of course, is the sharpest control instrument but is rarely used $;{ }^{57}$ control via committees of various kinds, including investigative committees; parliamentary control commissions, e.g., the commission responsible for overseeing the office of constitutional protection, and special persons, such as the personal data protection commissioner; informal controls, e.g., discussons in cabinet meetings, majority party group meetings which are also attended by a minister, or meetings between leaders of coalition parties, etc.; parliamentary control via the courts, where the minority parties have the right to bring matters before the Land or federal constitutional courts to determine the constitutionality of some action; and parliamentary control of government actions, such as review of state contracts, Bundesrat matters, EU questions, results of subject minister conferences, and planning decisions.$^{58}$ Of course the quality of the review of government actions taken in horizontal conferences of prime ministers and subject ministers ("third level") and in vertical conferences of bureaucrats ("fourth level") depends on the relationship between the government, the majority and minority parties; the time and information available; the feasibility of taking action when informal commitments have already been made, etc. ${ }^{59}$ Such conferences are what Frido Wagener was referring to when he spoke of vertikale Ressortkumpanei and vertikale Fachbrüderschaften (vertical ministerial cliques and vertical subject brotherhoods, respectively). ${ }^{60}$ While Wagener's terms carried critical and negative connotations, it has also been noted that such conferences are important mechanisms of coordination and information management between and among levels. ${ }^{61}$

As in the British House of Commons, legislative control activities, for example, through the increasing number of written and oral questions, now take up far more time in plenary sessions than legislation. Indeed, one former Land prime minister suggested to the author that too many deputies see their active participation in question time as a means of keeping busy and of justifying their full-time status at the expense of the time and energy of the civil servants who serve the government ministers and must gather the information to answer the questions.

As the above suggests, it is useful to distinguish among various kinds of control. Herbert Schneider, for example, has divided types of controls into policy direction, administrative performance, and specialist categories. In the question times set aside in parliament, "major questions" (Große 
Anfragen) are usually reserved for sessions devoted to policy issues; "small questions" (Kleine Anfragen) and individual questions from deputies are generally associated with administrative performance; and the more routine specialist control is exercised mostly in parliamentary committees. ${ }^{62}$

Other authors have noted the distinction between formal controls, e.g., those performed especially by the Opposition in public sessions through question time, and those that take place behind the scenes in the cabinet, internal party group meetings, party committees, etc. ${ }^{63}$

Parliamentary controls have different functions. The three most important are securing information, ${ }^{64}$ exercising influence on government actions and proposals, and promoting critical publicity. In addition, one can see control functions as serving to occupy a theme, to set the stage for a government pronouncement, to demonstrate to the public that the Land parliament is acting on some matter, and to make points against the other parties. ${ }^{65}$

Germans often distinguish between "working parliaments, " e.g., American legislatures, and "talking parliaments," e.g., the British House of Commons. German parliaments are both, but the "working" function is stronger. This is reflected above all in the time and effort devoted to committee work. ${ }^{66}$ Ministers and high-level civil servants spend a good deal of time in committee meetings, and the result is that deputies can develop considerable expertise in the subject matter and gain respect and influence in return. The committees meet usually from Tuesday through Thursday - except in Bavaria, Brandenburg, Rhineland-Palatinate, and Berlin usually in closed meetings - during special weeks set aside for that purpose, while plenary meetings of the parliament are held generally on the same days during one week a month for seven-ten months per year. While closed meetings may be problematic in terms of the transparency of committee actions, most German legislators are convinced that confidentiality is necessary to ensure serious work rather than public posturing and to limit interest group influence ${ }^{67}$ Another problem arises, however, when some committee actions or deliberations in the mostly nonpublic meetings are not communicated in plenary sessions of the parliament, so that noncommittee members may not be as well informed as they should be and there is less public information about the committees. ${ }^{68}$ The case for opening committee meetings to the public and press is often made, but it has not had much impact. ${ }^{69}$ On the other hand, it should be noted that the parliamentary petition committee in each Land receives all kinds of citizen complaints and requests and serves an ombudsman function quite effectively. 
Parliamentary control of finances is limited, as in most other parliamentary bodies, by the large proportion of expenditures that are fixed by law and not subject to political manipulation. In practice joint task expenditures made under Article 91a and 91b or Article 104a, para. 4, of the Basic Law are also not subject to revision by the Land parliamentary majorities because of their reluctance to refuse federal matching funds or reject actions of their own government. On the other hand, the deputies do receive reports of the Minister of Finance, and they can rely to a considerable extent on the Land general accounting office for ensuring costeffective administration, the director of which is named by the Land government. $^{70}$

As noted in other chapters, most federal laws are administered by the Länder. One of the problems Land parliaments face in their control of the administration of these laws is the lack of information. The best-informed civil servants may be in the federal ministries that drew up the legislation, and neither they nor their ministers can be made to appear before the Land parliaments to answer questions. ${ }^{71}$ The Land civil servants who actually implement the federal laws can always point to their federal origin (on the other hand, much legislation is changed to some extent in the Bundesrat, which is the domain of Land civil servants). Nevertheless, some questions raised in the Land parliaments refer to federal actions, sometimes even including foreign and defense policy. Of course these have no legal effect. ${ }^{72}$

A common complaint heard for the last few decades is that cooperative federalism - and more specifically, the joint and interlocking decision making by experts associated with the Politikverflechtung concept - largely removes the Land parliaments from a good deal of decision making and opportunities for control. Decision making in parliaments is more transparent than in governments, and when Land ministers and bureaucrats meet together in a wide variety of specialized conferences, and Land and federal officials meet to engage in joint planning efforts under the joint tasks of Article 91a and 91b, increased transparency and public information levels are not the result. Yet effective parliamentary control should result in making political responsibility visible. In cooperative federalism, however, decisions are largely the result of negotiated compromise by governments with little opportunity for parliamentary participation. ${ }^{73}$

\section{The debating function}

This function is concerned with political education, but even more with communication with constituents and party supporters. Debates are far less a means of persuading deputies on the other side than of scoring 
points and of confirming the views and wishes of and speaking to supporters with the aid of the media that report on activities in the Land parliament. This is especially important as elections approach.

Debates follow government declarations, major questions raised in question time, and bills that have been introduced. The Opposition has the obligation of pointing to contradictions, weaknesses in conception, problems of financing, and alternative provisions. Speakers for the majority party or coalition parties reflect the views of the government and not necessarily the real divisions that may exist internally. This, of course, can make the debates all too predictable and therefore boring. ${ }^{74}$ Some issues, such as the education and territorial reforms of the late 1960s and early 1970s already mentioned, enjoy considerable public interest. Most, however, do not. Even the introduction of the "Current-Issues Discussion" (Aktuelle Stunde) has done little to arouse public interest, perhaps in part because of the style and nature of the debates as well as the lack of public information and often limited press coverage.$^{75}$ There is probably little difference, however, between Land parliaments and state legislatures in the United States in the generally low level of public interest in their activities.

Debates are usually not as sharp in the Land parliaments as in the Bundestag, because their smaller size makes it possible for the delegates to know one another personally, and because Land parliaments enjoy a more collegial atmosphere. ${ }^{76}$ On the other hand, this does not prevent occasional sharp exchanges based on both ideological and personal differences.

\section{Representation and articulation function}

Representation can take on different meanings, depending on the context in which it is used. Alan Rosenthal, in his book on American state legislatures, distinguishes between political representation, deliberative representation, and descriptive representation. ${ }^{77}$ Political representation refers to such factors as reapportionment and redistricting of representative singlemember districts in order to provide equality and fairness. Deliberative representation has to do with the legislative process, information-gathering, legislative skills, linkage between issues, bargaining and compromise, and responsibility for decisions made. Descriptive representation suggests a mirror image of the voters in terms of income, occupation, age, race or ethnic group, and gender. No legislative body in the democratic world conforms to this image of representation, which would be achieved better by drawing lots than by holding elections. This is not to say that the increases in representation of women and minorities or changes in occupational 
backgrounds of legislators are not important or do not make a difference. But these new members are also not typical of the electorate they serve. Whether they can be said to "refine and enlarge the public views," as claimed by James Madison in Federalist no. 10 (1787), may depend on the time, place, issue, and perspective of the observer. Finally, a fourth kind of participatory representation, based on citizen initiatives, legislative initiatives and referenda, recall, etc., along with a greater focus on public opinion polls, is another alternative which has aroused great controversy in both the United States and Germany. ${ }^{78}$

In Germany parliament reflects the diversity of interests in the Land better than the prime minister or the cabinet, which is one reason why the argument is made that the weakening of parliaments vis-à-vis the governments must be resisted. ${ }^{79}$ This does not, of course, prevent some groups from maintaining that they are not represented. A good example is the environmentalists in the 1970s, who formed citizen initiatives in competition with elected bodies at both the local and Land levels. Since the early 1980s, however, these elements have formed and have been generally absorbed by the Greens, who have gained representation in all of the Land parliaments in the West (but none in the East!) and large numbers of local governments. ${ }^{80}$ Environmental concerns have also been picked up to a much greater extent than before by the older, established parties.

Parliamentary debating and articulation functions are closely related. Debating functions are shared with the media, and articulation functions are shared with interest groups. Group interests are, of course, also reflected in debates, and they are articulated in nonpublic committee meetings. ${ }^{81}$ The petition committees, mentioned above, should also be noted as instruments for connecting public concerns and demands with the Land parliaments.

\section{Service function}

This is a key function in the United States, where it involves a wide variety of constituency services. The amount and nature of service provided varies among the states, based largely on the amount of staff support the legislator has at his or her disposal. ${ }^{82}$ In Germany the service function is often ignored in the literature as a specific function of legislators, probably because Land legislators generally do not have staff other than perhaps a part-time secretary to assist them with such activities. On the other hand, they do have office hours in their constituencies or home towns, and they are often visited or contacted by individuals, groups, and local government officials who have various requests and concerns. ${ }^{83}$ They also 
receive numerous telephone calls in their homes from constituents, some of whom seem to pay little regard to the timing of their call. Furthermore, deputies would point to the many group meetings, festivals, ceremonies, etc., that they are expected to attend back home. The petition committee mentioned above should also be mentioned as a means of providing service functions.

\section{"Laboratory" function}

The German Länder are not in as strong a position as American states to perform a laboratory function in terms of new policy initiatives, such as the experiments carried out by several American states in the 1990s in the area of welfare reform. On the other hand, elections in the Länder may be seen at times as tests for the parties at the federal level, as in the case of Hesse in February 1999 where the CDU and FDP won an unexpected victory only months after the federal election in September 1998 which the SPD and Greens won clearly. Land elections also offer opportunities for new parties to demonstrate their seriousness and potential. Examples on the left would be the Greens in the 1980s and, after unification, the PDS in the eastern Länder; on the the far right, parties such as the Republikaner in the late 1980s and the German People's Party (DVU) in the 1990s have had some limited success. The formation of new Land government coalitions in the 1990s, such as the SPD and the Greens in Hamburg, Bremen, and Hesse, could be seen as the precursor of the SPD-Green coalition in Bonn in September 1998; whether the SPD and the PDS coalition in Mecklenburg-Vorpommern will become any kind of model for future coalitions in other Länder and perhaps even for the federal level remains to be seen. These examples in addition to the introduction of personal data protection procedures in Hesse and the vote for sixteen-year-olds in local elections in Schleswig-Holstein, Lower Saxony, and Hesse (changed again to age eighteen by the new CDU/FDP government in Hesse in summer 1999) have led some to conclude that "the Land level today is in spite of all unitary tendencies within certain limits a field for political experimentation." 84

\section{Land parliaments and governments}

As noted above, there is a tendency in all democratic systems, and especially in parliamentary democracies, for the executive to take major responsibility for setting the legislative agenda and for pushing its budgetary, fiscal and other policy proposals through the legislature. ${ }^{85}$ In all 
democratic systems the broader agenda is the result of increased governmental responsibilities in social, economic, transportation, environmental, educational, and other policy areas, while the success rate in passing agenda items is based on varying degrees of party discipline and size of the majority. In parliamentary systems it is also due to the interconnection between the government and the majority party or coalition in the parliament and the reluctance of this majority to challenge government policy and therefore weaken the government or even force the calling of new elections which would be difficult for the majority to contest if it was itself responsible for the downfall of its own government.

In Germany the institution of the Bundesrat, a federal organ which allows Land governments to participate in the federal legislative process, has contributed to what some observers call a system of "executive federalism." This is a system in which the federal government and its majority in the Bundestag can pass a majority of its legislative proposals - and usually the more important ones - if the Bundesrat, composed of Land government representatives, grants its approval. We have noted above that the federal government has assumed major responsibility for legislation in the German federal system as a result of a series of constitutional and other changes since the Basic Law was adopted in 1949. As will be seen in Chapter 11, the influence of the Land governments has also increased in recent years as a result of constitutional reforms providing the Bundesrat with additional powers in decision making concerning the EU. It is also clear that the influence of the Land governments increases under conditions of divided government, as in the 1990s and since 2000.

The problem with these developments from the perspective of the Land parliaments is that they have not benefited from the increased participation of their governments in federal decision making; indeed, the increase in Bundesrat legislative initiatives in the past few decades is in part a reflection of the loss of legislative powers in the Land parliaments. ${ }^{86}$ While Land governments do have an obligation to keep their parliaments informed, and parliaments may make recommendations to their governments, proposals to make Land government votes in the Bundesrat dependent on approval by Land parliaments have been rejected as both unconstitutional and impractical. They are unconstitutional because the Bundesrat is a federal organ over which the Land parliaments have no authority, and impractical because of time pressures and information levels. This results in the widespread complaint that the Land parliaments have been the real losers in the increased legislative powers of the federal government and the growth in participation of the Länder in many federal decisions via the Bundesrat. ${ }^{87}$ 
Not only are the Land parliaments left out of decision making in the Bundesrat; they have also been bypassed when the federal government passes concurrent legislation that calls on the Land governments to issue regulations for implementation without parliamentary action, ${ }^{88}$ a practice that was revised somewhat in favor of the Land parliaments in the constitutional amendments in $1994 .{ }^{89}$ The horizontal meetings of the Land prime ministers and of subject ministers (the so-called "third level") also lead to numerous agreements that, in theory, are subject to parliamentary scrutiny and approval; however, in fact the parliamentary majority is unlikely to reject its own government's actions, not only because of party discipline but also because of a lack of information. ${ }^{90}$ Model legislation may also emerge from such meetings. In addition, hundreds of specialized meetings involving higher civil servants of the Länder and meetings of federal and Land experts result in a large number of recommendations that are not legally binding but that in fact lead to a high degree of cooperation and coordination. These may be formally subject to Land parliament approval, but they have a unitary effect. Meetings of federal and Land bureaucratic officials (sometimes referred to as "the fourth level") may also lead to federal-Land agreements that can have an effect on laws or create bodies that do not affect the Land parliaments directly. ${ }^{91}$ It is not clear, however, just what the "proper" role of the Land parliaments should be in these circumstances, given the logic of the parliamentary system which calls for support of the government by the majority party or coalition parties.

\section{The role of Land parliaments}

In summary, the complaint that the Land parliaments have been weakened over the last few decades is, at least to some extent, a questionable proposition. If one looks only at the legislative functions they perform, they surely have been weakened; however, if one looks at other functions, their weakness is not so apparent.

Even if the Land parliaments have been weakened in their legislative function, it can be argued that they continue to perform other important functions, such as the election and recruitment, control, debating, representation, and service functions discussed above. Part of the problem the Land parliaments face in exercising these functions, however, is that their exercise often requires considerable expertise on the part of individual deputies, they take place in relative obscurity, and they appear generally to be less interesting to both the media and the public. The fact that it $s$ above all the role of the Opposition to exercise effectively many of 
the control functions - and in the process usually be easily defeated makes it more difficult to keep the media and public interested in routine legislative sessions.

Also when compared with parliamentary systems in other countries, it might be argued that it is not really so clear that German Land parliaments have lost significantly more power in general terms than parliamentary bodies elsewhere. If one looks at the role of governments in Great Britain or in any number of parliamentary systems in setting the agenda and relying on party cohesion to push through their policy initiatives, one could also point to a relatively passive law making role as performed by the parliament. One can also point to the general weakness of the French National Assembly or even the British House of Commons for comparative purposes. A strong legislature, after all, suggests an ability to defy the government in committees and in plenary sessions, to set its own agenda, and to act independently in general, not only in cases of divided government but even when the same party controls both the executive and legislative branches, as in the United States. But these are characteristics of a presidential or separation of powers system, not a parliamentary system in which the government and its supporting party or coalition parties are interconnected. The highly individualistic American model might mean that the legislature is more "responsive,"92 but it also suggests a less "responsible" party system and a less "responsible" government, because the voters cannot generally hold weak parties, divided government, or government with uncertain party support as such accountable for their actions. Even some Land parliament deputies who have complained to the author about the inability of their institution to act more independently of the government seemed unaware of the change to a system of separation of powers and weakened parties that a powerful Land parliament would imply.

This raises the question of whether at least some of the concern expressed about the weakening of Land parliaments is based on a misunderstanding of the parliamentary system. As one observer of the political scene in Germany has noted, the "loss" of power to the federal level and, increasingly, to the EU level, seems inevitable, and it helps little to whine about it; besides, the Länder are primarily concerned with administration, which is a key concern of the people, and therefore it is important for the Land parliaments to focus on control functions. This observer also notes that in a party democracy, such as Germany's, the natural obligation of the majority party in parliament is to support the government in implementing its proposals and program, but this calls for control measures both 
within and outside of parliament, e.g., the press. ${ }^{93}$ Another observer suggests that a parliamentary system "is basically a flagrant violation of the separation of powers, because the parliament and government ... are connected in a special way that is important to the functioning of parliament ... Therefore, in answering the question of what the Land parliaments can and should do, the principle of separation of powers has little relevance."94 Studies have shown, however, that most Germans believe that separation of powers is or should be a characteristic of their parliamentary system and that there is a widespread misperception of the roles of government and opposition parties in supporting and opposing the government and the leading role of the government in the legislative process. ${ }^{95}$ These studies are not very different in principle from studies that show that many Americans also do not understand their state legislatures, and, like many Germans, have unrealistic and contradictory expectations regarding legislators and the policy making process. It is no surprise that, as a result, they are supercritical. ${ }^{96}$

\section{The organization of the Land parliaments}

Like legislative bodies in the American states, each Land parliament has an administrative staff to assist the deputies in various aspects of their work. This administration is supervised by the President of the Landtag and led by a Landtagsdirektor. It is not a part of the executive branch; the staff are Land civil servants appointed by the President. From small numbers of higher-level civil servants and lower-level employees in the early 1950s, the total staff has grown to several hundred in the larger Länder. About half of the higher civil servants are employed by the parliamentary advisory service, which is concerned with numerous technical legislative services such as legislative bill drafting.

As in the United States, the size of the administrative staff has increased over the years as a result of improvements made in the levels and kinds of services provided; the increased work of the parliaments; the addition and growth of professional legislative services, due in part to the growing complexity of legislation; and the addition of press and information as well as visitors' services. ${ }^{97}$ The staff has the responsibility of supporting the parliament, its President, the committees, the party groups, and the deputies. It is divided into two sections: one concerned primarily with the preparation, implementation, and assessment of plenary, committee or commission meetings and the parliamentary petition office and public 
information; the other section is involved primarily with classic administration, such as payroll and record keeping.

\section{The parliamentary services section ${ }^{98}$}

\section{Legal services}

The main function of this office is to provide legal advice. This includes advice not only regarding legislation, constitutional issues, reports, and so forth, but also concerning rules of procedure. Legal advice for investigating committees can be especially important.

\section{The petitions office}

This office serves as a kind of parliamentary ombudsman for the many citizens who send requests or complaints to the parliament. The small staff check whether the petitions are admissible, organize meetings of the petitions committee or, in Lower Saxony, the standing committees, and plan visits by deputies to the locations of some complaints for a first-hand view of the situation. Recommendations are made by the petitions committee or other committees for relief or action by the bureaucracy or parliament. ${ }^{99}$

\section{The plenary meeting and committee service}

Here staff are responsible for preparing the regular committee meetings, the plenary meetings, and the meetings of the praesidium (executive committee) which sets the agenda and decides how much time should be available for discussion of each item. The staff assemble and print all relevant documents required for the plenary and committee meetings.

\section{Stenographic services}

Each parliament has several stenographers who have the task of recording every word spoken in the plenary sessions, including questions raised that interrupt the speeches and comments made by hecklers. They rotate about every five minutes, and their reports are printed about fourteen days after they were written. The record is not entirely verbatim, since small and obvious corrections are made. For committee meetings notes are kept rather than word-for-word accounts.

\section{Public relations and media services}

This is a more recent addition, and it has four areas of activity: the press, publicity, political education, and visitor services. The staff keep the press informed about parliamentary developments and the deputies informed 
about press reports concerning them and parliament. Each party group also has a press office of its own.

\section{The administration section ${ }^{100}$}

\section{Protocol}

One civil servant has the responsibility to prepare for foreign visitors, official receptions, and other events. He or she also prepares visits of the parliamentary president and deputies to foreign countries, especially for the purpose of visiting regional legislative bodies such as selected American state legislatures.

\section{The administration office}

This office is responsible for administering the budget of the parliament, including payments of salaries to the deputies and staff, support payments to the party groups, printing costs and building maintenance. The deputies also have their own part-time secretaries paid from the budget. Payment of party group staff is the responsibility of the party groups themselves. There is also a small staff of technical personnel who maintain the building.

\section{The information service}

This service includes the library - which is some Länder is very good archives, data collection, and so forth. The role of computers has become increasingly important in this area.

\section{The parliamentary advisory service ${ }^{101}$}

The purpose of this service is to advise and assist the party groups and the member deputies. The chair of the party group decides how to use the personnel assigned to the party group. They are selected by the parliamentary president in consultation with the party group, but they become public employees who must meet the civil service standards for the positions they occupy. Since they are civil servants, they cannot be released even if the party for whose parliamentary group they work no longer gains sufficient votes in parliamentary elections (i.e., 5 percent of the total) to be admitted to parliament. In this case they have to be assigned elsewhere. If the party groups hire persons not authorized in the budget, these persons do not become civil servants. 


\section{Conclusion}

Land parliaments were established before the federal parliament in 1949, and Article 30 and Article 70 of the Basic Law seem to suggest that they have very important legislative functions. But the Basic Law also grants the federation broad legislative powers, concurrent powers, and the authority to pass framework legislation. These provisions, constitutional amendments, and Federal Constitutional Court decisions that have expanded the legislative powers of the federation, the growing role of the Bundesrat which increases the influence of Land governments rather than Land parliaments, the growing regulative activities of the EU, and Politikverflechtung in general, have had the overall effect of reducing the legislative powers of the Land parliaments.

On the other hand, Land deputies exercise many functions besides law making, including electoral and recruitment functions, control functions, debating functions, representative and articulation functions, service functions, and, to some extent, "laboratory" functions. Of these, the most time-consuming for most deputies is the service function performed especially for the home district. The deputies, who have few or no staff, serve as a link between citizens and the government, including administrative offices, and thereby help to bring government "closer to the people."

It could be argued that the decline of legislative powers of the Land parliaments is also to some extent a reflection of the operation of the parliamentary system. This system calls for the majority party or parties to support the government in order to give it the legitimacy it needs to govern and to provide political stability. A legislature that can and does defy the head of government or competes with him or her and the cabinet for control of the agenda and the power to pass legislation that may not be supported by the cabinet suggests a different political model, namely the presidential system, characterized by separation of powers and checks and balances. There is some evidence that many Germans seem to expect more of a separation of powers than the parliamentary system provides and do not understand or accept the conventional roles of government, majority, and opposition in this system; nor do they respect the politicians who operate within the system. ${ }^{102}$ To the extent this thesis is correct, it is no wonder that there is widespread Politikverdrossenheit (alienation from or annoyance with politics) in Germany. 


\section{Notes}

1 Hermann Eicher, Der Machtverlust der Landesparlamente (Berlin: Duncker \& Humblot, 1988), pp. 23-27.

2 Ibid., pp. 31-38.

3 Ibid., pp. 38-40.

4 Ibid., pp. 77-78.

5 Martin Bullinger, "Die Zuständigkeit der Länder zur Gesetzgebung," Die öffentliche Verwaltung 23, no. 22 (November 1970), p. 765; Eicher, Der Machtverlust, p. 78.

6 Manfred Friedrich, Landesparlamente in der Bundesrepublik (Opladen: Westdeutscher Verlag, 1975), p. 55.

7 Otto Rundel, "Kontrolle der Fraktionsfinanzierung," in Der Landtag - Standort und Entwicklungen, edited by Erich Schneider (Baden-Baden: Nomos Verlagsgesellschaft, 1989), pp. 141-148.

8 For a list of rights and privileges associated with party group status, see Thomas Rösslein, “Die Fraktionen im Landtag," in Schneider, Der Landtag, p. 128.

9 Ibid., p. 126.

10 There is a vast literature in Germany on the tension between Article 21 of the Basic Law which is seen as promoting the "party state" and Article 38 of the Basic Law (and, of course, their counterparts in the Land constitutions) which prohibits deputies from acting on the basis of instructions against their own consciences. See, for example, Wilhelm Henke, Das Recht der politischen Parteien (2nd edn; Göttingen: Schwartz, 1972), p. 129 or Christoph Müller, Das Imperative und Freie Mandat (Leiden: Sijthoff, 1966), Ch. 5.

11 For a discussion of territorial and boundary reforms at the local level in Germany, see Arthur B. Gunlicks, "The Reorganization of Local Governments in the Federal Republic of Germany," in Local Government Reform and Reorganization: An International Perspective, edited by Arthur B. Gunlicks (Port Washington: Kennikat Press, 1981), pp. 169-181; and by the same author, Local Government in the German Federal System (Durham: Duke University Press, 1986), Ch. 4, and "Die parteipolitischen Präferenzen beim niedersächsischen Entscheidungsprozess für eine Gebietsreform im Spannungsfeld von Effizienz, Gleichheit und Freiheit," Zeitschrift_für_Parlamentsfragen 7, no. 4 (December 1976), pp. 472-488.

12 Herbert Schneider, Länderparlamentarismus in der Bundesrepublik (Opladen: Leske \& Budrich, 1979), p. 83.

13 Rösslein, “Die Fraktionen im Landtag,” pp. 129-134.

14 Ibid., pp. 134-135.

15 Schneider, Länderparlamentarismus, p. 82.

16 Walter Rudolf, "Die Bedeutung der Landesparlamente in Deutschland," in Die Stellung der Landesparlamente aus deutscher, österreichischer, und spanischer Sicht, edited by Detlef Merten (Berlin: Duncker \& Humblot, 1997), p. 60; 
Manfred Friedrich, Der Landtag als Berufsparlament? (Karl-Bräuer-Institut des Bundes der Steuerzahler, 1977), p. 29; Franz Gress, "Aktuelle Probleme und Perspektiven des Föderalismus in der Bundesrepublik Deutschland und den USA," in Krise und Reform des Föderalismus, edited by Reinhard C. MeierWalser and Gerhard Hirscher (München : Olzog Verlag, 1999), pp. 123-124; Bullinger, "Die Zuständigkeit,” p. 764.

17 Friedrich, Der Landtag als Berufsparlament?, p. 26.

18 I wish to thank Klaus-Eckart Gebauer, Director of the Cabinet Staff in Rhineland-Palatinate, for this reminder.

19 Gunlicks, “The Reorganization of Local Governments," pp. 169-181 and Gunlicks, Local Government, Ch. 4. For a comprehensive treatment, see Werner Thieme and Günther Prillwitz, Durchführung und Ergebnisse der kommunanlen Gebietsreform (Baden-Baden: Nomos Verlagsgesellschaft, 1981).

20 See the resolution by the Conference of Land Parliament Presidents, who complained in 1983 of the loss of legislative powers to the federation and the European Community. Unterrichtung durch den Präsidenten des Landtags, "Standortbestimmung und Perspektiven der Landesparlamente," Landtag Rheinland-Pfalz, Drucksache 10/22 (1 June 1983).

21 This is the argument made by the president of the Bavarian Land parliament, Johann Böhm, in his "Grußwort," in Die Abgeordneten: Stellung, Aufgaben und Selbstverständnis in der parlamentarischen Demokratie, edited by Heinrich Oberreuter (Tutzing: Akademie für politische Bildung, 1995), pp. 9-10.

22 Albrecht Martin, "Möglichkeiten, dem Bedeutungsverlust der Landesparlamente entgegenzuwirken," Zeitschrift für Parlamentsfragen 15, no. 2 (1984), p. 279; Friedrich, Der Landtag als Landesparlamente, p. 55; Friedrich, Berufsparlament?, p. 26.

23 On the other hand, he has complained about the growing focus of attention in the parliaments on local matters and the decreasing attention paid to political leadership issues and principles. In this regard he has warned against the deputies' becoming mere spokespersons for public concerns. See Erik Spemann, "Schlanker Staat durch Schrumpfkur für das Parlament," Das Parlament (14 November 1997), p. 16.

24 Rudolf, “Die Bedeutung," p. 70.

25 Jens Kalke, "Bedeutungsverlust der Landtage? Ein empirischer Test anhand der Drogenpolitik," Zeitschrift fürParlamentsfragen 32 (May 2001), pp. 309325.

26 Winfried Steffani, "Länderparlamentarismus im parlamentarischen Bundesstaat," in Liberale Demokratie in Europa und den USA: Festschrift für Kurt L. Shell, edited by Franz Gress and Hans Vorländer (Frankfurt: Campus Verlag, 1990), pp. 208-222.

27 Schneider, Länderparlamentarismus, p. 49.

28 Rudolf, "Die Bedeutung," p. 58. For a list of constitutional changes between 1963 and 1992 that granted more powers to the federation at the expense of 
the Länder, see Albert Janssen, "Der Landtag im Leineschloß - Entwicklungslinien und Zukunftsperspektiven," in Rückblicke - Ausblicke, edited by Präsident des Niedersächsischen Landtages (Hannover: Hahn-Druckerei, 1992), pp. 38-40.

29 Rudolf, “Die Bedeutung,” p. 52; Eicher, Der Machtverlust, p. 77.

30 Eicher, Der Machtverlust, pp. 103-104.

31 Ibid., p. 86.

32 Martin, “Möglichkeiten," pp. 279, 281.

33 Konrad Hesse, Der unitarische Bundesstaat (Karlsruhe: C. F. Müller, 1962).

34 Wilfried Erbguth, "Erosion der Länderstaatlichkeit," in Verfassungsrecht im Wandel, edited by Jörn Ipsen (Köln: Heymann, 1995), pp. 559-561.

35 Eicher, Der Machtverlust, p. 63.

36 Hartmut Klatt, "Beziehungen zwischen Bundestag and Landesparlamenten. (Selbst-) Entmachtung der Landesparlamente? Möglichkeiten und Gegenstrategien," in Landesparlamente und Föderalismus: Hat das parlamentarische System in den Bundesländern eine Zukunft?, edited by Franz Gress (Wiesbaden: Hessischer Landtag, 1990), p. 83.

37 The author most associated with this concept is Fritz Scharpf. For example, see Fritz Scharpf, Bernd Reissert, and Fritz Schnabel, Politikverflechtung: Theorie und Empirie des kooperativen Föderalismus in der Bundesrepublik Deutschland (Kronberg: Scriptor Verlag, 1976); Martin, "Möglichkeiten," pp. 280-281.

38 Rudolf, "Die Bedeutung," p. 64.

39 Friedrich, Der Landtag als Berufsparlament?, pp. 22-24.

40 Janssen, Der Landtag, p. 25.

41 Eicher, Der Machtverlust, p. 83.

42 Ibid., pp. 48-52.

43 Ibid., pp. 53-60.

44 Heiderose Kilper and Roland Lhotta, Föderalismus in der Bundesrepublik Deutschland (Opladen: Leske \& Budrich, 1996), p. 199.

45 Ibid. See also Roland Johne, Landesparlamentarismus im Zeichen der europäischen Integration (Frankfurt/M.: Peter Lang, 1994), p. 36.

46 Eicher, Der Machtverlust, p. 30; Roland Hahn, Macht und Ohnmacht des Landtages von Baden-Württemberg (Kehl: N. P. Engel Verlag, 1987), p. 6; Franz Gress and Roland Huth, Die Landesparlamente: Gesetzgeungsorgane in den deutschen Ländern (Heidelberg Hüthig, 1998), Ch. 2.

47 Schneider, Länderparlamentarismus, p. 47.

48 Erich Schneider in the preface of Der Landtag-Standort und Entwicklungen, p. 8.

49 Schneider, Länderparlamentarismus, p. 51.

50 Roland Hahn, Macht und Ohnmacht des Landtages von Baden-Württemberg (Kehl: N. P. Engel Verlag, 1987), p. 7.

51 Schneider, Länderparlamentarismus, pp. 34-35. 
52 Ibid., pp. 31-33.

53 Rudolf, “Die Bedeutung," p. 56.

54 Schneider, Länderparlamentarismus, p. 38; see also the allegations of Tammany Hall-like conditions in Cologne, in Erwin and Ute Scheuch, Cliquen, Klüngel und Karrieren: Über den Verfall der politischen Pareien (Reinbek bei Hamburg: Rowolht, 1993).

55 Roland Hahn even notes that sometimes members of the Bundestag forward mail to their counterparts in the Landtag, because it concerns questions of administration that are the responsibility of the Länder. Hahn, Macht und Ohnmacht, p. 32.

56 Friedrich, Landesparlamente, p. 11; Hahn, Macht und Ohnmacht, p. 11; Rudolf, “Die Bedeutung," p. 70.

57 On the other hand, what appeared to be a rather routine change of leadership in mid-term for the SPD-FDP coalition in Lower Saxony in 1976 led to a change of government when the coalition majority failed in a secret ballot to provide the prime minister's replacement with an absolute majority vote. The end result was the election of the CDU's Ernst Albrecht as the new prime minister. Arthur B. Gunlicks, "Coalition Collapse in Lower Saxony: Political and Constitutional Implications," Parliamentary Affairs 29, no. 4 (Autumn 1976), pp. 437-449.

58 Joachim Linck, "Die parlamentarische Kontrolle der Landesparlamente," in Die Kontrollfunktion der Landesparlamente, edited by Heinz Schäffer (Wien: Manzsche Verlags- und Universitätsbuchhandlung, 1995), pp. 14-20.

59 Eicher, Der Machtverlust, pp. 96-98.

60 Frido Wagener, "Gemeinsame Rahmenplanung und Investitionsfinanzierung," Die öffentliche Verwaltung 30, no. 16 (August 1977), p. 588; "Milderungsmöglichkeiten nachteiliger Folgen vertikaler Politikverflechtung," in Politikverflechtung im föderativen Staat, edited by Joachim Jens Hesse (Baden-Baden: Nomos Verlagsgesellschaft, 1978), pp. 149-165.

61 Klaus-Eckart Gebauer, "Interessenregelung im föderalistischen System," in Grundrechte, soziale Ordnung und Verfassungsgerichtsbarkeit, edited by Eckart Klein (Heidelberg: C. F. Müller Juristischer Verlag, 1995), p. 89.

62 Schneider, Länderparlamentarismus, pp. 39-41; also Herbert Schneider, "Der Landtag," in Baden-Württemberg: Eine politische Landeskunde, edited by der Landeszentrale für politische Bildung (3rd edn; Stuttgart: Verlag W. Kohlhammer, 1985), pp. 97-99.

63 Gress and Huth, Die Landesparlamente, p. 47.

64 Gebauer, "Interessenregelung," p. 72.

65 Linck, "Die parlamentarische Kontrolle," p. 28.

66 Rüdiger Voigt, "Einfluß und Wirkungsmöglichkeiten der Landesparlamente," Bayerische Verwaltungs-Blätter, no. 4 (15 February 1977), p. 98.

67 Schneider, Länderparlamentarismus, p. 85

68 Friedrich, Landesparlamente, pp. 15-16, 20-21, 26-27. 
69 Schneider, Länderparlamentarismus, pp. 85-86.

70 Ibid., pp. 42-43.

71 Walter Leisner, "Schwächung der Landesparlamente durch grundgesetzlichen Föderalismus,” Die öffentliche Verwaltung 21, no. 11-12 (June 1968), pp. 389-396; Friedrich, Landesparlamente, p. 34.

72 Linck, "Die parlamentarische Kontrolle," p. 23.

73 Eicher, Der Machtverlust, pp. 66-69.

74 Hahn, Macht und Ohnmacht, p. 20.

75 Hans Meyer, "Was sollen und was können die Landesparlamente leisten?," in Gress, Landesparlamente und Föderalismus, p. 52; Schneider, Länderparlamentarismus, pp. 55-61.

76 Ibid., pp. 54-55.

77 Alan Rosenthal, The Decline of Representative Democracy: Process, Participation, and Power in State Legislatures (Washington, DC: CQ Press, 1998), pp. 27-31, 39-43; see also Werner Patzelt, Abgeordnete und Repräsentation: Amtsvertändnis und Wahlkreisarbeit (Passau: Wissenschaftsverlag Rothe, 1993), Ch 1. Chapter 1 draws heavily from Hanna F. Pitkin, The Concept of Representation (Berkeley: University of California Press, 1967).

78 Rosenthal, The Decline, pp. 31-39.

79 Eicher, Der Machtverlust, pp. 65-66.

80 Ibid., pp. 62-63.

81 Ibid., p. 63.

82 Rosenthal, The Decline, pp. 15-17.

83 Werner J. Patzelt, Abgeordnete und ihr Beruf: Interviews - Umfragen - Analysen (Berlin: Adademie Verlag, 1995), pp. 94-102.

84 Gress and Huth, Die Landesparlamente, pp. 54-57.

85 Thus it is the governments on which the press focuses its attention. Dietrich Herzog et al., Abgeordnete und Bürger: Ergebnisse einer Befragung der Mitglieder des 11. Deutschen Bundestages und der Bevölkerung (Opladen: Westdeutscher Verlag, 1990), pp. 32-33.

86 Georg-Berndt Oschatz and Horst Risse, "Bemerkungen zum Gesetzesinitiativrecht des Bundesrates," Zeitschrift für Gesetzgebung 4, no. 4 (1989), pp. 316331.

87 Eicher, Der Machtverlust, pp. 88-89; Friedrich, Landesparlamente, p. 71; Evelyn Haas, "Die Mitwirkung der Länder bei EG-Vorhaben," Die öffentliche Verwaltung 41, no. 15 (August 1988), pp. 621-622.

88 Eicher, Der Machtverlust, pp. 92-93.

89 Rudolf, “Die Bedeutung," p. 61.

90 Eicher, Der Machtverlust, p. 94.

91 Ibid., pp. 94-98; Martin, “Möglichkeiten,” pp. 280-281.

92 Rosenthal, The Decline, pp. 327-328.

93 Paul Leo Giani, "Was könnte besser gemacht werden? Partei, Regierung, und Parlament. Die Praxis der Landespolitik," in Gress, Landesparlamente und Föderalismus, pp. 129-131, 133. 
94 Hans Meyer, “Was sollen und was können die Landesparlamente leisten?," in Gress, Landesparlamente und Föderalismis, p. 36.

95 Werner Patzelt, "Ein latenter Verfassungskonflikt? Die Deutschen und ihr parlamentarisches Regierungssystem," Politische Vierteljahresschrift 39 (1998), pp. 725-757.

96 Rosenthal, The Decline, pp. 67-69, 340-343; Patzelt, Abgeordnete und ihr Beruf, pp. 193-197.

97 Wolfgang Krauter, "Die Verwaltungsinfrastruktur des Parlaments - ihre Entwicklung in den letzten 25 Jahren," in Schneider, Der Landtag - Standort und Entwicklung, pp. 155-156.

98 The information in this section is based on material describing the services provided in Baden-Württemberg as provided in ibid., pp. 159-164.

99 See also Schneider, Länderparlamentarismus, pp. 107-112.

100 Krauter, “Die Verwaltungsstruktur,” pp. 166-168.

101 Ibid., pp. 172-175.

102 This is the theme of the article by Patzelt, "Ein latenter Verfassungskonflikt?," pp. 725-757. 